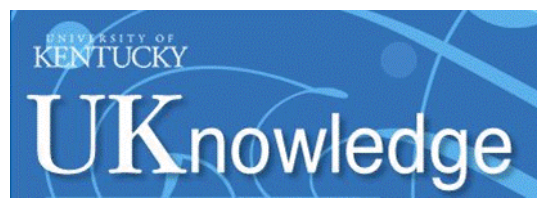

University of Kentucky

UKnowledge

\title{
Preventing Horse-Related Injuries by Watching Out for Other Humans
}

William R. Gombeski Jr.

University of Kentucky, william.gombeskijr@uky.edu

Fernanda C. Camargo

University of Kentucky, fccama2@uky.edu

Holly Wiemers

University of Kentucky, hfwiem2@uky.edu

Connie Jehlik

The United States Pony Clubs, Inc.

Polly Haselton Barger

Certified Horsemanship Association

See next page for additional authors

Follow this and additional works at: https://uknowledge.uky.edu/animalsci_facpub

Part of the Animal Sciences Commons, Community Health and Preventive Medicine Commons, and the Recreation, Parks and Tourism Administration Commons

Right click to open a feedback form in a new tab to let us know how this document benefits you.

\section{Repository Citation}

Gombeski, William R. Jr.; Camargo, Fernanda C.; Wiemers, Holly; Jehlik, Connie; Barger, Polly Haselton; and Mead, James, "Preventing Horse-Related Injuries by Watching Out for Other Humans" (2017). Animal and Food Sciences Faculty Publications. 19.

https://uknowledge.uky.edu/animalsci_facpub/19

This Article is brought to you for free and open access by the Animal and Food Sciences at UKnowledge. It has been accepted for inclusion in Animal and Food Sciences Faculty Publications by an authorized administrator of UKnowledge. For more information, please contact UKnowledge@lsv.uky.edu. 


\section{Preventing Horse-Related Injuries by Watching Out for Other Humans}

Digital Object Identifier (DOI)

https://doi.org/10.1016/j.jort.2017.05.003

\section{Notes/Citation Information}

Published in Journal of Outdoor Recreation and Tourism, v. 19, p. 11-16.

(c) 2017. This manuscript version is made available under the CC-BY-NC-ND 4.0 license https://creativecommons.org/licenses/by-nc-nd/4.0/

The document available for download is the authors' post-peer-review final draft of the article.

\section{Authors}

William R. Gombeski Jr., Fernanda C. Camargo, Holly Wiemers, Connie Jehlik, Polly Haselton Barger, and James Mead 


\title{
RESEARCH ARTICLE
}

\section{Preventing horse-related injuries by watching out for other humans}

\author{
William R. Gombeski Jr. ${ }^{a}$; Fernanda C. Camargo ${ }^{b}$; Holly Wiemers ${ }^{c}$; Connie Jehlik ${ }^{\text {d; }}$ \\ Polly Haselton Barger ${ }^{e}$; James Mead ${ }^{f}$
}

${ }^{\mathrm{a}}$ Department of EVPHA Marketing; UK HealthCare; 2355 Huguenard Dr, Suite 200;

Lexington, KY USA 40503

(bill.gombeski@uky.edu)

${ }^{b}$ Department of Animal and Food Sciences; N212G Ag. Science Bldg. North;

University of Kentucky; Lexington, KY USA 40546-0091

(Fernanda.camargo@uky.edu)

'Department of Ag-Equine Programs; N212G Ag. Science Bldg. North;

University of Kentucky; Lexington, KY USA 40536-0091

(holly.wiemers@uky.edu)

dThe United States Pony Clubs, Inc., 4041 Iron Works Parkway

The Kentucky Horse Park; Lexington, KY USA 40511-8483

(instruction@ponyclub.org)

${ }^{\text {e}}$ Certified Horsemanship Association; 1795 Alysheba Way, \#7102; Lexington, KY USA 40509

(pbarger@CHA-ahse.org)

fDepartment of Marketing; University of Houston - Clear Lake; 2700 Bay Area Boulevard;

Houston, TX USA 77058

(mead@uhcl.edu)

\section{Corresponding Author:}

William R. Gombeski Jr.

Senior Advisor

UK HealthCare

2355 Huguenard Drive, Suite 200

Lexington, Kentucky USA 40503

Ph: 859-257-2296 Fax: 859-257-5509

bill.gombeski@uky.edu 


\section{Abstract}

The more one rides or handles horses, the more likely one is to have a horse-related injury. These injuries are caused by many factors, including those generated by other riders, handlers or spectators. An analysis of 266 cases of injured equestrians showed that $16 \%$ of those injuries were caused by other humans. A panel of horse riding safety experts felt $63 \%$ were preventable, and the injured individuals themselves felt $51 \%$ were preventable. The study findings suggest that increased awareness of the role others play in causing horse-related injuries and increased education about common people-caused injuries could reduce the number of horse-riding and handling injuries, and medical visits to physicians, emergency rooms, and hospitalizations.

Management Implications: Horse riding organizations and businesses such as guest ranches, horse parks, and training centers, which bring many individuals together with various levels of equine experience, should include an orientation to horse safety, especially noting the role of other humans in causing injuries, that explains how to avoid some of the most common accidents.

Keywords: Horse-related injury; accident; safety; prevention 


\section{Introduction:}

Horse-riding and handling injuries occur to even the most safety-conscious and experienced equestrians. Indeed, Mayberry, et al (2007) report in a study of 679 equestrians that $81 \%$ had experienced at least one horse riding injury in their lifetime and that $21 \%$ had experienced a severe injury requiring surgery, hospitalization, or rehabilitation. The percentage with a serious injury rose to $37 \%$ for those who were professional equestrians/instructors. A review of the medical and equestrian literature shows $38 \%$ to $64 \%$ of horse-related injuries are preventable according to studies of injured riders (Huhnke, et al 1997; Newton \& Nielson 2005; Ball, et al 2009; Ekberg, 2011). While none of these studies indicated that other riders or persons were responsible for the injury, riders regularly hear of injuries caused by another rider or person. Despite anecdotal claims suggesting their occurrence, there appears to be a gap in the literature detailing the frequency, nature, and outcomes of another rider or person involved in riding accidents.

A broader examination of the sports and recreation literature regarding accidents or injuries reveals that "other human involvement" has been studied and identified as a cause of accident or injury. An assessment by Rome, et al (2014) determined that 93 out of 202 (46\%) bicycle accidents involved another person. Motorists caused $45 \%$ of the other-person injuries, $41 \%$ were caused by other bicyclists, and $14 \%$ were caused by pedestrians. The assessment did not find any significant differences in severity of injures by cause. Two general studies in which sports/recreation and play activities were included reported the role of other people as a cause of accidents. Hemenway and Solnick (2011) surveyed youth in grades 9 through 12 in Boston 
public schools and asked if they had caused an unintentional injury to someone else in the past year. Seventeen percent said they had. The second, a study of Swedish day care center injuries (Sellstrum, et al 1994), determined that $13 \%$ of injuries to children were caused by other children. Data was not collected on whether the injury was intentional or not. These studies show that other humans do generate unintentional injuries although none addressed recommendations for reducing injuries from other humans.

In this research, we use data collected by SaddleUp SAFELY, a University of Kentucky initiative supported by 40 other equine-related organizations, to document and investigate the potential role other people or riders play in equestrian riding accidents. The State of Kentucky's role in the equine industry and sport is well known. In the reported research, we attempt to make a substantive contribution to the equestrian and safety literature. Specifically, our empirical exploration of the frequency, nature, and outcomes of another rider or person involved in riding accidents may bring awareness to a yet undocumented risk factor of horserelated injuries. It is our hope that increased awareness may aid those within the equestrian and safety communities in reducing the risks of future "other human" involved riding accidents.

\section{Methods:}

SaddleUp SAFELY, a coalition of more than $\mathbf{4 0}$ medical and horse organizations, was launched in 2009 to raise awareness of horse-related injuries, reduce the frequency and severity of horse-related injuries, and encourage injured riders to return to the sport. SaddleUp SAFELY also established the website SaddleUPSAFELY.org to provide and promote horse riding and handling safety information for equestrians and other industry stakeholders. In an attempt 
to better understand and prevent horse-related injury, SaddleUpSAFELY.org offers a form where individuals who have had an injury or accident can report detailed information regarding the nature and circumstances surrounding their horse-related injuries. To better understand if and where increased educational efforts should be focused, an analysis of these injured rider forms was conducted. Analysis of this data allows us to study equestrian injuries and answer the question of what role do other humans play in causing horse-related injuries.

The SaddleUpSAFELY.org injury form allows respondents to explain how the horserelated injury occurred, what area(s) of the body were injured and how badly, and if they were hospitalized and/or went to the emergency room, saw a doctor or other medical professional, missed school or work, or lost employment. Further, respondents were asked to provide a detailed account of the circumstances surrounding their injury, as well as advice for how others might avoid a similar injury in the future. Additional information, such as horse-related experience (e.g., ride occasionally to ride weekly or more often; whether they raise or keep horses; how they rate their horse riding experience - advanced, professional, intermediate, beginner, novice; whether they compete at an amateur or professional level; or if they earn their living working with horses) was also collected.

The website with the injury form was launched in October 2009. By November 2012, 342 individuals filled out the injury/safety tip form. Of the 342 visitors, 42 provided safety tips only and 36 of the injury forms had insufficient data, resulting in 264 individual responses. Because one individual submitted two injuries on a form, a total of 265 cases were available for analysis. 
The forms were jointly reviewed, discussed and quantitatively coded by a team of four equestrian experts associated with the Kentucky 4-H Horse Program, The U.S. Pony Clubs, the Certified Horsemanship Association, and the University of Kentucky Ag Equine Programs. Appendix A provides a complete list of the coded causes of injury.

The causes of the injuries generated by other humans were further analyzed and grouped into categories. Figure 1 provides examples of injuries caused by: 1) not using equipment correctly, 2) handler using poor judgment, 3) poor public understanding of horse behavior, 4) misleading information, and 5) poor riding behavior/etiquette.

The first category, "didn't use equipment correctly", includes any reason where the equipment was applied incorrectly or the wrong equipment was selected. "Handlers/others using poor judgment" refers to situations where a poor decision or action by others generated the injury. "Poor riding behavior/etiquette" includes others not monitoring their horse and following too closely or interfering with the riding of others. "Misleading or important information not shared" included facts about the horse's behavior and training, whether the horse was on medications, or the suitability of the trail. The category of "public's poor understanding of horse behavior" was defined as injuries caused by non-horse people such as someone setting off fireworks, throwing Frisbees at horses, automobiles honking, and not controlling dogs.

All coding discrepancies were debated and solved by review consensus. The data was then coded and entered into a SPSS file. Chi-square analysis was employed to assess the presence and nature of significant relationships between rider skill level and the probability a 
given rider experienced another human-caused injury, where the other human-caused injuries took place, and how other human-caused injuries compared to injures caused by other factors in terms of their likelihood to result in rider hospitalization. Interrater reliability assessments, measured with Cohen's Kappa, were also employed to assess level of agreement between respondents' and equestrian experts' assessments regarding the preventability of other humancaused injuries. To provide an adequate treatment and discussion of the topic and data in this research, attention is focused on factors related to injuries caused by the involvement of other humans.

\section{Results:}

Table 1 describes the self-reported riding level of the study respondents as well as the information regarding their accident/injury type. Overall, our data show that $16 \%$ (41 of 265) of the injuries were because of the behavior/error of another human ( $17 \%$ for novice/beginner riders, $12 \%$ for intermediate riders, and $23 \%$ for advanced/professional riders). A chi-square test of independence revealed a marginally significant relationship between riders of intermediate $\left(\chi^{2}(1, N=265)=3.51, p=.06\right)$ and advanced $/$ professional $\left(\chi^{2}(1, N=265)=\right.$ $3.13, p=.07$ ) riding levels and riders who reported an injury caused by human factors. That is, intermediate riders were marginally less likely to report horse-related injuries caused by other humans than would be expected, whereas advanced/professional riders were marginally more likely to report an injury caused by a human factor, given each of the group proportions in the dataset. Conversely, a chi-square test of independence did not find a significant relationship 
between the frequency of injuries caused by other humans or non-human factors for novice/beginner riders $\left(\chi^{2}(1, N=265)=.19, p=.66\right)$.

To explore these results further, we conducted several additional chi-square analyses to compare the frequency of injuries caused by other humans or non-human factors between riders of different self-reported skill levels. Results revealed that beginner and intermediate level riders reported statistically similar amounts of injuries caused by other humans $\left(\chi^{2}(1, N=\right.$ $203)=1.25, p=.27)$, as did beginner and advanced $/$ professional riders $\left(\chi^{2}(1, N=126)=\right.$ $.57, p=.51)$. However, advanced/professional and intermediate level riders did experience a marginally significant difference in the amount of injuries caused by other humans $\left(\chi^{2}(1, N=\right.$ 201) $=4.14, p=.054)$. That is, the odds of a human factor horse injury were greater for advanced/professional riders relative to intermediate riders; see Table 2.

Further, a chi-square (with Fisher's Exact Test correction for expected cells less than 5) of independence was performed to assess whether other human-caused injuries were more or less likely to occur in different riding area (e.g., the barn, pasture, or trail). Results indicated that no relationship was found between the location of the injury event and whether the injury was the result of human or non-human factors ( $p>.10$ in all cases).

To investigate if riders involved in other human-related injury experienced different injury outcomes, we conducted another series of chi-square tests of independence; see Table 3. Results indicate that riders injured by other humans were no more likely to seek medical attention $\left(\chi^{2}(1, N=265)=1.57, p=.25\right)$ or visit an emergency room $\left(\chi^{2}(1, N=265)=\right.$ 
$1.97, p=.17)$ than those injured by other factors. However, riders injured by other humans were significantly more likely to report ultimate hospitalization for their injuries $\left(\chi^{2}(1, N=\right.$ $265)=10.33, p=.002$ ) than those injured by other factors. Perhaps not surprising given the significant difference in hospitalization rates between riders involved in other humans vs. other factors accidents, riders involved in other human-caused accidents also report significantly more cases of missed work or school due to their injury $\left(\chi^{2}(1, N=265)=4.97, p=.033\right)$. However, the proportion of injured riders indicating their injury was preventable, whether caused by another human or other factors, was similar. Our expert reviewers felt only $51 \%$ of injuries caused by other humans were preventable as compared to $82 \%$ for injuries caused by other factors.

The first two columns of Table 4 show the frequency and percentage of cause of injuries by other humans. "Didn't use equipment correctly" and "handler/others using poor judgment" were the top causes at $24 \%$ each. "Public's poor understanding of horse behavior," 22\%, "poor riding behavior and etiquette," at $20 \%$, and "misleading information or no information shared" at $10 \%$ were the other categories of causes. In general, "did not use equipment correctly" was viewed by both riders and the four experts as highly preventable at $90 \%$ each. While the $n$ of 4 for "misleading or no information shared" was small, $75 \%$ of riders and $100 \%$ of the experts viewed accidents caused by this issue preventable. Sixty percent of both the riders and experts indicated that accidents caused by "handler/others using poor judgment" were preventable. The other two categories, "public's poor understanding of horse behavior" and "poor riding behavior/etiquette" were viewed as preventable by riders and experts $50 \%$ or less of the time. 
The interrater reliability for riders and equestrian experts regarding the preventability of the injuries presented in Table 4 was found to be Cohen's Kappa $=0.60, \mathrm{p}<.0 .01,95 \% \mathrm{Cl}(0.35$, 0.86), representing a moderate level of agreement (Landis \& Koch, 1977). That is, riders and equestrian experts were moderately likely to agree regarding whether a given human-caused injury was preventable or not.

\section{Discussion:}

Overall, $16 \%$, or almost one out of every six injuries in this study, was due to another human. Equestrians injured by another human were also more likely to be hospitalized (44\%) than those injured due to other causes (21\%). Because handling and riding horses usually takes place around and with other equestrians or the public, increased awareness and promotion of how those injuries/accidents can occur should be a regular part of safety briefings, orientation, and training.

Our analysis shows that somewhere between half and two-thirds of these injuries could have been prevented based on the injured rider's opinion and our expert's assessment of their accidents. We therefore believe that education and awareness are paramount in avoiding preventable accidents. Table 3 indicates that some causes are more preventable than others. Injuries caused by improper use of equipment, poor handler judgment, and missing or misleading information were viewed as preventable at $60 \%$ or higher. Poor riding etiquette and the public's poor understanding of horse behavior, which had lower levels of preventability, require broader education campaigns aimed at both equestrians and the public. 


\section{Management Implications:}

The findings suggest several uses. First, instruction and training should be provided to those around or riding horses to raise awareness about accidents that are caused by others. 


\section{Limitations:}

There are limitations with the data we collected. First, it is self-initiated. Participants had to find out about our website and accident-reporting form. So the group that responded is more likely to have internet access and be comfortable using the internet. It is likely our research participants are more educated and motivated about horse riding and handling safety than the general horse riding population.

Second, the data is self-reported and retrospective. There can be discrepancies between actual and remembered facts. Haegeli, et al (2011) and Boyd, et al. (2009) both indicated that minor injuries are often underreported in those injured by avalanches. Gabbe, et al (2013) did note that major elements of an injury are more likely to be recalled a year later as opposed to minor details. Therefore it is likely that there is some inaccuracy in the data reported in our study as there was no limit on time since injury and it is likely minor injuries were not reported. 


\section{Conclusions:}

Overall, $16 \%$ of the injuries in this study were caused by other humans. Many humaninduced, horse-related accidents can be prevented. Keeping an eye out for other equestrians and spectators, providing proper instruction or training to those assisting in horse-related activities, and general education to the public about horse behavior are important actions to prevent injuries to yourself and others. 


\section{References}

Ball, J., Ball, C., Mulloy, R., Datta, I., \& Kirkpatrick, A. (2009) Ten years of major equestrian injury: are we addressing functional outcomes, Journal of Trauma Management and Outcomes, 3, 1-5.

Bavarian, B., Mehrkhanl, F., Ziaee, V., Youseti, A., \& Nourian, R. (2009) Sensitivity and specificity of self-reported symptoms for exercise-induced bronchospasm diagnosis in children. Iran Journal of Pediatrics, 19, 47-51.

Boyd, J., Haegeli, P., Abu-Laban, R. B., Shuster, M., \& Butt, J.C. (2009) Patterns of death among avalanche fatalities: a 21-year review. Canadian Medical Association Journal, 180, 507-512.

Ekberg, J., Timpka, T., Ramel, H., \& Valter, L. (2011) Injury rates and risk-factors associated with eventing: a total cohort study of injury events among adult Swedish eventing athletes.

International Journal of Injury Control and Safety Promotion, 18, 261-267.

Gabbe, B. J., Finch, C. F., Bennell, K. L., \& Wajswelner, H. (2013) How valid is a self-reported 12 month sports injury history? British Journal of Sports Medicine, 37, 545-547.

Haegeli, P. H., Falk, M. Brugger, H., Etter, H., \& Boyd, J. (2011) Comparison of avalanche survival patterns in Canada and Switzerland. Canadian Medical Association Journal, 183, 1-7.

Hemenway, D. \& Solnick, S. (2011) The unintentional injurer: results from the Boston youth survey. American Journal of Public Health, 101, 663-668.

Huhnke, R., Hubert, D., \& Harp, S. (1997) Identifying injuries sustained on cow calf operations in Oklahoma. St Joseph, Michigan. American Society of Agricultural Engineers, Paper No. 975010.

Landis, J. R. \& Koch, G. G. (1977). The measurement of observer agreement for categorical data. Biometrics, 33, 159-174.

Lubeck, D.P. \& Hubert, H.B. (2005) Self-report was a viable method for obtaining health care utilization data in community-dwelling seniors. Journal of Clinical Epidemiology, 58, 286-290.

Mayberry, J., Pearson, T., Wiger, K., Diggs, B., \& Mullins, R. (2007) Equestrian injury prevention efforts need more attention to novice riders. The Journal of Trauma, Injury, Infection and Critical Care, 62, 735-739.

Mitchel, R., French, C. \& Boufous, S. (2010) Counting organized sport injury cases: Evidence of incomplete capture from routine hospital collections. Journal of Science Medicine in Sport, 13, 304-308.

Newton, A. M. \& Nielson, A. M. (2005) A review of horse-related injuries in a rural Colorado hospital: implications for outreach education. Journal of Emergency Nursing, 31, 142-146. 
Rome, L., Boufous, S., Georgeson, T., Senserrick, T., Richardson, D., \& Ivers, R. (2014) Bicycle crashes in different riding environments in the Australian Capital Territory. Traffic Injury Prevention, 15, 81-88.

Sellstrom, E., Breberg, S., \& Chang, A. (1994) Injuries in Swedish day-care centers. Pediatrics, 94, 1033-1036.

Stathokostas, L., Theou, O., Vandervoort, T., \& Raina, P. (2012) Psychometric properties of a questionnaire to assess exercise-related musculoskeletal injures in older adults attending a community based fitness facility. British Medical Journal Open, 22, pii: e001777. doi:

10.1136/bmjopen-2012-001777 


\section{Figure 1 - Examples of Other Human Injury Causes by Category}

\section{Didn't use equipment correctly}

Bit was too tight and horse started bucking before friend's uncle could walk around to fix the bit.

I let someone else tack up the horse and failed to check it before we took off. The rear girth strap slipped and touched his scrotum and he kicked both hind legs catapulting me over his head.

\section{Handler/others using poor judgment}

Parents had just bought horse but didn't have saddle yet. Daughter wanted to ride so they let her. Daughter fell off.

Friend was holding horse's bridle while I mounted. He pulled down on the reigns causing the horse to rear up.

\section{Public's poor understanding of horse behavior}

We were trail riding near a park and a man under the influence thought it would be funny to throw a Frisbee at our horses. My horse spooked and took off.

Van approached us from behind. I was on side of road and van started honking which caused horse to look back and it stumbled.

\section{$\underline{\text { Misleading information }}$}

Sold unsafe horse - horse was drugged when we bought him.

My husband and I adopted a rescued horse for the first time. The rescue organization told us the horse could walk, trot, canter, side pass, pen gate and negotiate trail obstacles. After trotting 10 seconds he bolted. We found out later the horse had bolted with its previous trainers and had a history of bolting.

\section{Poor riding behavior/etiquette}

My horse was cut off by another horse and rider which caused my horse to trip.

Careless rider's horse bumped injured rider's horse outside gate causing injured rider's horse to fall. 
Table 1 - Information about Equestrians and Injuries

\begin{tabular}{|c|c|c|}
\hline & $\underline{\mathrm{n}}$ & $\underline{\%}$ \\
\hline \multicolumn{3}{|l|}{ Riding Level } \\
\hline Novice/Beginner & 64 & $24 \%$ \\
\hline Intermediate & 139 & $53 \%$ \\
\hline Advanced/Professional & 62 & $23 \%$ \\
\hline \multicolumn{3}{|l|}{ Where Accident Happened } \\
\hline Barn & 20 & $8 \%$ \\
\hline Pasture & 31 & $12 \%$ \\
\hline Arena & 59 & $22 \%$ \\
\hline Trail & 55 & $21 \%$ \\
\hline Trailer & 10 & $4 \%$ \\
\hline Round Pen & 2 & $1 \%$ \\
\hline Other & 88 & $33 \%$ \\
\hline \multicolumn{3}{|l|}{ Seriousness of Injury } \\
\hline Hospitalized & 64 & $24 \%$ \\
\hline Emergency Room Not Hospitalized & 84 & $32 \%$ \\
\hline Sought Medical Attention Not ER & 44 & $17 \%$ \\
\hline Did Not Seek Medical Attention & 73 & $28 \%$ \\
\hline \multicolumn{3}{|l|}{ Preventability - Rider's Opinion } \\
\hline$\overline{\text { Yes }}$ & 175 & $64 \%$ \\
\hline No & 90 & $34 \%$ \\
\hline \multicolumn{3}{|l|}{ Preventability - Expert Assessment } \\
\hline Yes & 204 & $77 \%$ \\
\hline No & 61 & $23 \%$ \\
\hline
\end{tabular}


Table 2 - Relationship between Riding Level and Accidents Caused by Other Humans Accident Caused by Other Human

$\begin{array}{cc}\text { No } & \text { Yes } \\ \text { Count } & \text { Count }\end{array}$

Novice and Beginner

53

11

Intermediate

123

16

Advanced and Professional

48

16 
Table 3 - Seriousness of Injury by Cause of Injury

\begin{tabular}{|c|c|c|c|c|c|c|}
\hline Seriousness of Injury & \multicolumn{2}{|c|}{$\underline{\text { Total }}$} & \multicolumn{2}{|c|}{ Injured by } & \multicolumn{2}{|c|}{$\begin{array}{c}\text { Injuries by } \\
\text { Other Factors }\end{array}$} \\
\hline Hospitalized & 64 & $24 \%$ & 18 & $44 \%$ & 46 & $21 \%$ \\
\hline Emergency Room Not Hospitalized & 84 & $32 \%$ & 9 & $22 \%$ & 75 & $33 \%$ \\
\hline Sought Medical Attention not ER & 44 & $17 \%$ & 6 & $15 \%$ & 38 & $17 \%$ \\
\hline Did Not Seek Medical Attention & 73 & $27 \%$ & 8 & $20 \%$ & 65 & $29 \%$ \\
\hline Missed School or Work & 95 & $36 \%$ & 21 & $51 \%$ & 74 & $33 \%$ \\
\hline TOTAL & $\underline{265}$ & $100 \%$ & $\underline{41}$ & $\underline{15 \%}$ & $\underline{224}$ & $\underline{85 \%}$ \\
\hline
\end{tabular}




\section{Table 4 - Categories of "Other Human" Caused Injury(ies)}

\begin{tabular}{|c|c|c|c|c|}
\hline \multirow[b]{2}{*}{ Cause of Injury } & \multirow[b]{2}{*}{$\underline{\mathrm{n}}$} & \multirow[b]{2}{*}{$\underline{\%}$} & \multicolumn{2}{|c|}{ Injury Preventable } \\
\hline & & & Riders & Experts \\
\hline Didn't use equipment correctly & 10 & $24 \%$ & $90 \%$ & $90 \%$ \\
\hline Handler/other using poor judgment & 10 & $24 \%$ & $60 \%$ & $60 \%$ \\
\hline Public's poor understanding of horse behavior & 9 & $22 \%$ & $33 \%$ & $22 \%$ \\
\hline Poor riding behavior/etiquette & 8 & $20 \%$ & $50 \%$ & $25 \%$ \\
\hline Misleading or no information shared & 4 & $10 \%$ & $75 \%$ & $100 \%$ \\
\hline Total & 41 & $100 \%$ & & \\
\hline
\end{tabular}


Appendix A

Table A1 - Causes of Injury

\begin{tabular}{|c|c|c|c|c|}
\hline \multirow[b]{2}{*}{ Cause } & \multicolumn{2}{|c|}{ Total Sample } & \multicolumn{2}{|c|}{ Other Human } \\
\hline & $\underline{\mathbf{n}}$ & $\underline{\%}$ & $\underline{\mathbf{n}}$ & $\underline{\%}$ \\
\hline Horse Spooked & 71 & $27 \%$ & 11 & $27 \%$ \\
\hline Error, Other Human & 41 & $16 \%$ & 41 & $100 \%$ \\
\hline Green Horse & 29 & $11 \%$ & 1 & $2 \%$ \\
\hline New Horse & 28 & $11 \%$ & 9 & $22 \%$ \\
\hline Error, Other Horse & 25 & $9 \%$ & 5 & $12 \%$ \\
\hline Tack/Equipment Problem & 25 & $9 \%$ & 6 & $15 \%$ \\
\hline Jumping & 24 & $9 \%$ & 0 & $0 \%$ \\
\hline Horse Tripped/Fell & 20 & $8 \%$ & 4 & $10 \%$ \\
\hline Other & 19 & $7 \%$ & 3 & $7 \%$ \\
\hline Runaway Horse & 18 & $7 \%$ & 5 & $12 \%$ \\
\hline Horse Refused & 17 & $6 \%$ & 0 & $0 \%$ \\
\hline III-Mannered Horse & 16 & $6 \%$ & 2 & $5 \%$ \\
\hline Hit Horse's neck/body/head & 15 & $6 \%$ & 3 & $7 \%$ \\
\hline Mount/Dismount & 13 & $5 \%$ & 1 & $2 \%$ \\
\hline Mud/Rain/lce/Slick & 13 & $5 \%$ & 1 & $2 \%$ \\
\hline Holes in Ground/Obstacle & 12 & $5 \%$ & 0 & $0 \%$ \\
\hline Saddle Slipped & 11 & $4 \%$ & 1 & $2 \%$ \\
\hline No Safety Check & 11 & $4 \%$ & 5 & $12 \%$ \\
\hline $\begin{array}{l}\text { Horse Keeping/ } \\
\text { Maintenance }\end{array}$ & 11 & $4 \%$ & 4 & $10 \%$ \\
\hline Unsafe Speed & 10 & $4 \%$ & 0 & $0 \%$ \\
\hline Fresh Horse & 10 & $4 \%$ & 1 & $2 \%$ \\
\hline Horse Tripped & 10 & $4 \%$ & 2 & $5 \%$ \\
\hline $\begin{array}{l}\text { Loose Horse in } \\
\text { Pasture/Gate }\end{array}$ & 9 & $3 \%$ & 1 & $2 \%$ \\
\hline Rider Fell/Handler Fell & 8 & $3 \%$ & 1 & $2 \%$ \\
\hline Incorrect Leading & 7 & $3 \%$ & 1 & $2 \%$ \\
\hline Incorrect Riding Apparel & 7 & $3 \%$ & 1 & $2 \%$ \\
\hline Horse Not Tied/Tying & 7 & $3 \%$ & 2 & $5 \%$ \\
\hline Horse Slipped & 7 & $3 \%$ & 0 & $0 \%$ \\
\hline Not Clear & 7 & $3 \%$ & 1 & $2 \%$ \\
\hline Tack Broke & 6 & $2 \%$ & 2 & $5 \%$ \\
\hline In horse's space & 6 & $2 \%$ & 1 & $2 \%$ \\
\hline Weather (Heat/Cold) & 5 & $2 \%$ & 1 & $2 \%$ \\
\hline Buddy/Barn Sour Behavior & 5 & $2 \%$ & 2 & $5 \%$ \\
\hline Horse III, Sore Back & 4 & $2 \%$ & 1 & $2 \%$ \\
\hline Human Medical Problems & 2 & $1 \%$ & 0 & $0 \%$ \\
\hline Incorrect Lunging & 1 & $0 \%$ & 0 & $0 \%$ \\
\hline
\end{tabular}

* Multiple causes were allowed 